\title{
Disentangling the relationship between sociotropic and egotropic trade attitudes: A survey experiment in Japan
}

\author{
Eddie Hearn (i) \\ Faculty of Global Communications, Doshisha University, 1-3 Tataramiyakodani, Kyotanabe, Kyoto 610-0394, Japan \\ Corresponding author. Email: ehearn@mail.doshisha.ac.jp
}

(Received 18 September 2018; revised 31 March 2019; accepted 28 July 2019; first published online 16 September 2019)

\begin{abstract}
Public support for protection is typically attributed to economic self-interest. Beyond pocketbook anxieties, a competing approach, however, contends that sociotropic attitudes dictate foreign policy preferences. Researchers, however, have faced difficulty in disentangling sociotropic attitudes from pocketbook concerns in observational studies. This article addresses this problem by utilizing a priming experiment to examine the relationship between socio and egotropic attitudes. In line with the predictions of the sociotropic framework, individuals are less certain about the egotropic effects of trade and sociotropic attitudes are found to influence egotropic perceptions by reducing uncertainty about the pocketbook effects of trade. In contrast, the study fails to find support for the hypothesis that individuals project egotropic concerns onto societal evaluations. The results of the study suggest that future research should pay careful consideration to the relationship between socio and egotropic attitudes when modeling and analyzing trade-policy preferences.
\end{abstract}

Key words: Free trade; protectionism; public opinion

Public support for policies that protect the domestic economy is often attributed to individual selfinterest. Those who face labor-market risks as a result of globalization, for example, are predicted to support barriers to globalization such as protectionist trade policies and limits to immigration (Scheve and Slaughter, 2001a, 2001b; Mayda, 2006). Anxiety related to globalization is further argued to influence national voting patterns (Jensen et al., 2017; Owen and Walter, 2017; Colantone and Stanig, 2018). Competing research, on the other hand, contends that concerns about the national economy, or sociotropic attitudes, dictate foreign-policy preferences; suggesting that support for economic nationalism may not be driven by individual self-interest as it is often portrayed (Mansfield and Mutz, 2009; Hainmueller and Hiscox, 2010). Researchers, however, have faced difficulty disentangling sociotropic attitudes from pocketbook concerns in observational studies. This article addresses this problem by employing a survey experiment to directly examine the relationship between egocentric and sociotropic trade attitudes.

The article proceeds first with a brief overview of the self-interest and sociotropic approaches to trade-policy preference formation highlighting the difficulty in parsing out the causal direction of attitudes in observational research. The study utilizes a priming experiment embedded into a national survey to examine the relationship between socio and egotropic attitudes. The priming experiment allows for a direct test of the influence of self-interest on sociotropic attitudes and vice versa. Finally, the effect of sociotropic and egotropic attitudes on trade-policy preference formation is analyzed.

Sociotropic attitudes are found to significantly impact egotropic attitudes toward trade mainly through reducing uncertainty about the personal impact of trade. On the other hand, egotropic 
evaluations have no influence on sociotropic attitudes toward trade. When using comparable measures, however, both egotropic and sociotropic attitudes are found to impact trade-policy preferences. Individual self-interests remain an important factor in trade-policy preference formation, but most individuals are unaware of the personal impact of trade. Sociotropic perceptions are leveraged to reduce this uncertainty and form pocketbook evaluations. The article is concluded with a brief discussion of the implications of these findings on trade politics in Japan.

\section{Public opposition to trade}

Individual trade-policy preferences form the foundation of the political economy of trade (Scheve and Slaughter, 2001b). Pocketbook or individual economic interests are commonly seen as the starting point for understanding trade attitudes. Those who benefit directly as result of trade should support open policies while those who face increased competition as a result of liberalization have an economic incentive to favor protection.

The majority of research attempting to assess the impact of individual economic interest on tradepolicy preferences has focused on testing the predictions of the Heckscher-Ohlin $(\mathrm{H}-\mathrm{O})$ model. ${ }^{1}$ The $\mathrm{H}-\mathrm{O}$ model contends that differences in factor endowment drive international trade and factors are perfectly mobile between industries. The $\mathrm{H}-\mathrm{O}$ model thus predicts that trade will bring benefits to individuals who possess the relatively abundant factor in a country. Countries with a relative abundance of capital, for example, will specialize in goods that intensively use capital and import those that are labor intensive. An increase in trade openness would subsequently lead to gains for capital owners and skilled workers. Individuals who own the relatively scarce factor, on the other hand, will face declining wages and increased job-market risks as a result of trade liberalization. Low-skill workers in capital-abundant economies, for instance, will face increased job-market insecurity as a result of competition from imported labor-intensive goods. It is thus anticipated that owners of the economy's abundant factor will support liberalization, while owners of the scarce factor will favor economic nationalism.

Early studies mainly provided indirect tests of the theory without explicitly examining individual preferences (Kaempfer and Marks, 1993; Beaulieu, 2002). Beaulieu (2002), for example, finds that votes cast in the 1988 Canadian federal election which many believed to be a referendum on the Canadian-US Free Trade Agreement are consistent with the predictions of the $\mathrm{H}-\mathrm{O}$ model. Scheve and Slaughter $(2001 b)$ considerably advance this literature by directly examining the relationship between individual trade attitudes and factor endowment. ${ }^{2}$ The authors find that the skill-level, measured by education, significantly influences attitudes. ${ }^{3}$ In line with the factors model, low-skill individuals in the US express higher levels of support for trade protection. A number of studies using education as a measure of skill find additional support for the $\mathrm{H}-\mathrm{O}$ model's predictions in the US and other advanced industrialized economies (O'Rourke and Sinnott, 2001; Hays et al., 2005; Mayda and Rodrik, 2005; Sanz and i Coma, 2008). ${ }^{4}$

A large literature, however, has called into question the role of self-interest in attitude formation challenging the foundation of many political economy of trade models. Following theory from social

\footnotetext{
${ }^{1}$ These predictions are typically tested against those of the Ricardo-Viner (R-V) model which assumes factors are not perfectly mobile between industries. Most of the recent discussion of pocketbook versus sociotropic interests, however, focuses upon studies adopting the $\mathrm{H}-\mathrm{O}$ model.

${ }^{2}$ Balistreri (1997) directly analyzes Canadian support for CAFTA. It is important, however, to consider attitudes toward preferential trade agreements distinctly form general trade attitudes (Spilker et al., 2016).

${ }^{3} \mathrm{~A}$ number of studies question the use of education as a proxy for skill. Hainmueller and Hiscox (2006), for example, argue that education's relationship to trade attitudes is driven by learning about economic theory and cosmopolitan values not labor market concerns.

${ }^{4}$ These results have not been replicated in developing economies where the H-O predicts a negative relationship between education and support for trade. Ardanaz et al. (2013) argue that the positive effect of skill found in developing economies is consistent with New Trade Theory.
} 
and political psychology, it is argued that individuals form policy preferences not based on pocketbook interests but on sociotropic attitudes about a policy's perceived effect on the nation in general. ${ }^{5}$

A number of studies have analyzed the relative impact of sociotropic vs egocentric attitudes on voting and policy preferences. Many pointing out that egocentric attitudes rarely predict political attitudes. In line with previous work on economic voting in comparative and American politics, Mansfield and Mutz (2009) demonstrate that pocketbook interests, measured by the skill level, are no longer a predictor of trade-policy preferences after controlling for sociotropic attitudes. ${ }^{6}$ Similarly, Hainmueller and Hiscox (2010) fail to find support for pocketbook interests driving attitudes toward immigration.

Previous studies attempting to determine the relative importance of sociotropic vs egocentric attitudes on policy preferences, however, have faced a number of limitations. First, the observed dominance of sociotropic attitudes may simply be an artifact of the measurement of individual and social interests. Lockerbie (2006), for example, shows that the missing relationship between individual interests and voting is at least partially driven by differences in question wording for measures of individual and collective interests. When equivalent measures are used, both egocentric and sociotropic interests become important in vote choice.

Moreover, many studies adopt a very narrow view of self-interest. For example, while most studies focus on the predictions of the $\mathrm{H}-\mathrm{O}$ model, the Ricardo-Viner model (R-V) provides competing expectations. Unlike the $\mathrm{H}-\mathrm{O}$ model, the $\mathrm{R}-\mathrm{V}$ model contends that factors are not perfectly mobile between industries. An increase in trade openness thus benefits those in the exporting sector and harms those in import-competing industries regardless of individual factor endowments such as skill level. A number of studies have found both direct and indirect support for the sectors model (Magee, 1978; Irwin, 1994; Hays et al., 2005; Mayda and Rodrik, 2005).

Moreover, there is a considerable amount of experimental and empirical evidence that calls into question the links between skill-level, sector of employment, and trade attitudes. Rehm (2009) finds that occupation is the key factor in determining trade attitudes not sector of employment or factor endowment. Similarly, Owen and Johnston (2017) argue that occupation characteristics provide the important link between globalization and labor market exposure. Rho and Tomz (2015), however, find that skill level and perceived factor mobility do not influence attitudes toward trade in specific industries as predicted by the $\mathrm{R}-\mathrm{V}$ and $\mathrm{H}-\mathrm{O}$ models. Although, later research contends that providing cues about the distributional effect of trade strengthens the relationship between pocketbook interests and protectionist sentiments (Rho and Tomz, 2017). Likewise, information primes are found to increase the role of self interest in monetary-policy preferences (Bearce and Tuxhorn, 2017). Individuals face difficulty in tying national economic policy to narrow pocketbook outcomes.

Beyond labor-market insecurity, competing models of economic interests emphasize the impact of consumption on pocketbook concerns (Baker, 2003, 2005; Naoi and Kume, 2015; Hearn, 2017). Furthermore, individual interests are intertwined with larger societal effects (Scheve and Slaughter, $2001 b$ ). Studies that rely solely on the skill level to account for pocketbook concerns are thus too narrow to make claims about the relative impact of self-interests on trade attitudes.

Moving past the either-or debate that pits pocketbook interests in competition with societal concerns, additional strands of research have attempted to combine the sociotropic and egocentric approaches by modeling policy preferences as a combination of the two. Much of this research attempts to understand when individuals rely on collective vs individual assessments. Gomez and Wilson (2001), for example, argue that only sophisticated voters can make the complex connection

\footnotetext{
${ }^{5}$ Additional strands of research have suggested factors beyond self-interest that influence trade attitudes such as values, perceptions about harm and fairness, as well as out-group attitudes (Ehrlich, 2010, 2018; Hearn, 2014; Lü et al., 2012; Mansfield and Mutz, 2009).

${ }^{6}$ This interpretation, however, is not without criticism. The causal relationship between sociotropic attitudes and tradepolicy preferences is unclear (Fordham and Kleinberg, 2012). Individuals who are opposed to trade are more likely to view trade as harmful to society and vice versa. This endogeneity problem makes it difficult to understand the relationship between the attitudes which are routinely examined with observational studies.
} 
between personal finances and government policy. Others have highlighted the importance of values, identity, and media on individuals' decision to focus on personal vs societal cues when forming policy preferences (Feldman, 1982; Weatherford, 1983; Gomez and Wilson, 2001).

Continuing this tradition, Guisinger (2017) models the expected benefits of trade as a combination of personal and sociotropic benefits. Each individual weighs the importance of the personal and communal benefits of trade when forming a policy preference. An individual who completely emphasizes personal benefits, for example, would operate under the egocentric model. At the other extreme, an individual that focuses solely on communal benefits would reduce to the sociotropic model.

Research utilizing a heterogeneous approach, however, assumes socio and egocentric interests are conceptually distinct. Guisinger (2017: 76), for example, states 'the benefit to self and others are conceptually distinct, they are likely to be correlated in practice... This correlation does not mean that the concepts are not separable.' There are competing arguments, however, that contend social and personal concerns are not only empirically but conceptually linked. Curtis (2014: 420-421), for example, argues that 'pocketbook concerns play a greater role than typically given credit for and operate in a more complex, causally heterogeneous way than specified in standard frameworks.' No work, however, has specifically examined the relationship between sociotropic and egotropic trade preferences.

\section{Disentangling sociotropic and egotropic attitudes}

Following information-based sociotropic models, it is difficult for individuals to make connections between personal pocketbook concerns and national policy. Individuals thus rely on information about the perceived societal effects of a policy when forming an opinion. Individuals, however, are not forming altruistic preferences but internalizing sociotropic effects to their personal situation. Sociotropic attitudes are thus predicted to drive egotropic attitudes mainly by providing information. Hypothesis 1 is derived to examine this claim.

H1: Considering the sociotropic effects of trade influences attitudes about the personal effects of trade.

In contrast, proponents of the egotropic approach have argued that egotropic attitudes influence sociotropic attitudes. First, individuals project their personal pocketbook experiences onto society in general. This may explain why some studies fail to find support for pocketbook predictions after controlling for sociotropic attitudes (Curtis, 2014). Second, individual interests are intertwined with larger societal effects. Home owners, living in regions dominated by import-competing sectors, for example, have a pocketbook interest in supporting protection to maintain asset values (Scheve and Slaughter, 2001b). At the extreme, this would suggest no difference between pocketbook and sociotropic interests. To test the prediction that sociotropic attitudes are influenced by pocketbook evaluations, the following hypothesis is derived.

H2: Considering the personal effects of trade influences attitudes about the sociotropic effects of trade.

The following section introduces the research design and experiment used to test the above hypotheses. By utilizing a randomized priming experiment with a national sample, the relationship between the two attitudes can be clearly examined.

\section{Research design}

To examine the relationship between sociotropic and egotropic trade attitudes, a priming experiment is employed. The experiment was embedded into a national survey distributed by Survey Sampling International (SSI). SSI specializes in survey research, and SSI samples are commonly used in political 
science including studies examining foreign-policy attitudes (Malhotra et al., 2013; Kertzer and Brutger, 2016; Quek, 2017). The sample $(n=1,000)$ was recruited to match the Japanese national population on gender and age. The recruited sample further mirrors the Japanese population's skill level (education) and income distribution (Table 1). The study was conducted online, and data was collected from October 27 to November 6, 2017.

While much research has examined public opinion towards trade liberalization in developed economies, most studies have focused upon the US and Western Europe. Some analyses have included Japan at the aggregate level (Mayda and Rodrik, 2005), but very few studies focus specifically on the determinants of trade-policy preferences in the world's third largest economy. Four studies focusing on Japan have produced mixed results in relation to predictions of both the $\mathrm{H}-\mathrm{O}$ and $\mathrm{R}-\mathrm{V}$ models. This lack of support, however, should be taken cautiously as one of these studies addresses the determinants of attitudes toward agricultural trade (Naoi and Kume, 2011), another analyzes attitudes toward a specific trade agreement - the Trans-Pacific Partnership (TPP) (Naoi and Urata, 2013), and a third while focusing on general trade attitudes does not directly test the effect of factor endowment or sector of employment on preference formation (Naoi and Kume, 2015). A fourth study by Tomiura et al. (2016) finds mixed support for the $\mathrm{R}-\mathrm{V}$ predictions and support for the $\mathrm{H}-\mathrm{O}$ model.

Despite the relative lack of focus, it is important to consider the Japanese case. Japan's labor market differs from many other developed economies. As a result of a declining population, Japan maintains low unemployment rates and faces difficulty in finding workers for many vulnerable industries, particularly those requiring unskilled labor such as agriculture. Furthermore, over a quarter of the Japanese population is above the retirement age. Trade may thus be less likely to be viewed through a labor-market anxiety lens in Japan. Furthermore, Japanese citizens for cultural and social reasons may place a greater emphasis on social cohesion than their American and European counterparts.

To disentangle the relationship between societal and pocketbook interests, it is first necessary to measure egocentric and sociotropic trade attitudes. Specifically, how do respondents believe international trade is affecting them personally and society in general? This perception about the impact of trade is, after all, the foundation of many political economy models. To avoid making assumptions about competing economic models or unnecessarily limiting the scope of self-interest, a direct measure of egocentric trade attitudes is created. The following question is used: As you may know, international trade has increased a great deal in the last 20 years. Do you think that the growth in international trade has made things better or made things worse for you personally? (1) Made things better, (2) Made things worse and (3) Not sure. ${ }^{7}$ This approach measures self-interest in general as opposed to assuming factor endowment, employment sector, consumption, or occupation drives individual trade attitudes.

An identical question is employed to gauge sociotropic attitudes: As you may know, international trade has increased a great deal in the last 20 years. Do you think that the growth in international trade has made things better or made things worse for the Japanese in general? (1) Made things better, (2) Made things worse and (3) Not sure. This enables a direct comparison between sociotropic and egocentric perceptions as the only difference between the questions is changing the 'you personally' to 'the Japanese in general.'

Second, a priming experiment is incorporated to examine the causal relationship between egocentric and sociotropic trade attitudes. Following Ehrlich and Hearn (2014), a survey question is used to prime respondents. Respondents are randomly assigned to two groups (Groups A and B). Respondents in Group A $(n=501)$ receive the egocentric measure first followed by the sociotropic measure. Participants in Group B $(n=499)$ receive sociotropic measure first and the egocentric measure directly after. There are thus four groups, two control groups and two treatment groups (Table 2).

The ego-control group $(n=501)$ is asked directly about the perceived egocentric effects of trade with no manipulation (Group A). The socio-control group, similarly, responds directly to the sociotropic trade measure with no manipulation (Group B). These control groups provide the comparison groups to test the effects of the experimental treatments. The respondents in the socio-treatment group are first

${ }^{7}$ The survey is conducted in Japanese. See supplemental material for original Japanese question wording and survey design. 
Table 1. Summary of sample and national descriptive statistics

\begin{tabular}{|c|c|c|c|}
\hline Variable (range) & Median (S.D.) & Sample $(N=1,000)$ & National population ${ }^{a}$ \\
\hline Age $(1-10)$ & $7^{\mathrm{b}}(3.11)$ & & \\
\hline (Elderly 65+) & & $24.1 \%(n=241)$ & $26.7 \%$ \\
\hline Male $(0-1)$ & $0(0.500)$ & $48.3 \%(n=483)$ & $47 \%$ \\
\hline Female $(0-1)$ & $1(0.500)$ & $51.7(n=517)$ & $53 \%$ \\
\hline Education (1-11) & $7^{\mathrm{c}}(2.81)$ & & \\
\hline College graduate & & $41.9 \%(n=419)$ & $45 \%$ \\
\hline Income $(1-10)$ & $3^{d}(2.82)$ & & \\
\hline (Mean income) & & 5-6 million yen & 5.3 million yen \\
\hline
\end{tabular}

a Based on 2010 census data.

${ }^{b}$ Age 7 corresponds to the age bracket 50-54.

${ }^{\mathrm{c}}$ Education 7 corresponds to a Junior college graduate.

dincome 3 corresponds to 4-5 million yen.

Table 2. Experimental design

\begin{tabular}{|c|c|}
\hline $\begin{array}{l}\text { Group A } \\
(n=501)\end{array}$ & $\begin{array}{l}\text { Group B } \\
(n=499)\end{array}$ \\
\hline $\begin{array}{l}\text { Egocentric measure } \\
\text { (Ego control) } \\
\downarrow \uparrow \\
\text { Sociotropic measure } \\
\text { (Ego treatment) }\end{array}$ & $\begin{array}{l}\text { Sociotropic measure } \\
\text { (Socio control) } \\
\downarrow \uparrow \\
\text { Egocentric measure } \\
\text { (Socio treatment) }\end{array}$ \\
\hline
\end{tabular}

primed to consider the sociotropic effects of trade before reporting egocentric attitudes (Group B). Those in the ego treatment are conversely primed to think about the egocentric effects of trade before responding to the sociotropic measure (Group A). The priming experiment, therefore, considers the effect of sociotropic (egocentric) attitudes on egocentric (sociotropic) attitudes by priming respondents to think about the sociotropic (egocentric) effects of trade before measuring participants' perceptions about the personal (societal) impact of international trade.

\section{Results $^{8}$}

The results of the survey are presented in Figures 1 and 2. First, it is important to consider the outcome of the randomization process. An analysis of group assignment and response ID indicates that there is no relationship between respondents' order and group. Further analysis failed to identify any unbalanced covariates between Group A and B. The randomization process thus performed as expected. ${ }^{9}$

Hypothesis 1 predicts that priming about the sociotropic effects of trade will influence perceptions about the personal effects of trade. To examine this hypothesis, we can compare the perceived personal impact of trade of the ego-control group to that of the socio-treatment group. The ego-control group is directly asked the egotropic measure, how has international trade affected you personally, while the socio-treatment group receives the egotropic measure after responding to the sociotropic measure. The only difference between the two groups is the sociotropic priming. Any change in the perceived personal effects of trade between the groups can thus be attributed to the treatment.

The results are displayed in Figure 1. In line with the predictions of the socio-tropic model, thinking about the sociotropic effects of trade influences personal trade attitudes. Results from a chi-squared test indicate that the two groups are significantly different, $\chi^{2}(2, N=1,000)=9.20, P=0.01$ (Table 3 ). To

\footnotetext{
${ }^{8}$ All data analyzed in this study are available at https://doi.org/10.7910/DVN/KZK409.

${ }^{9}$ See supplemental material for details concerning the randomization checks.
} 


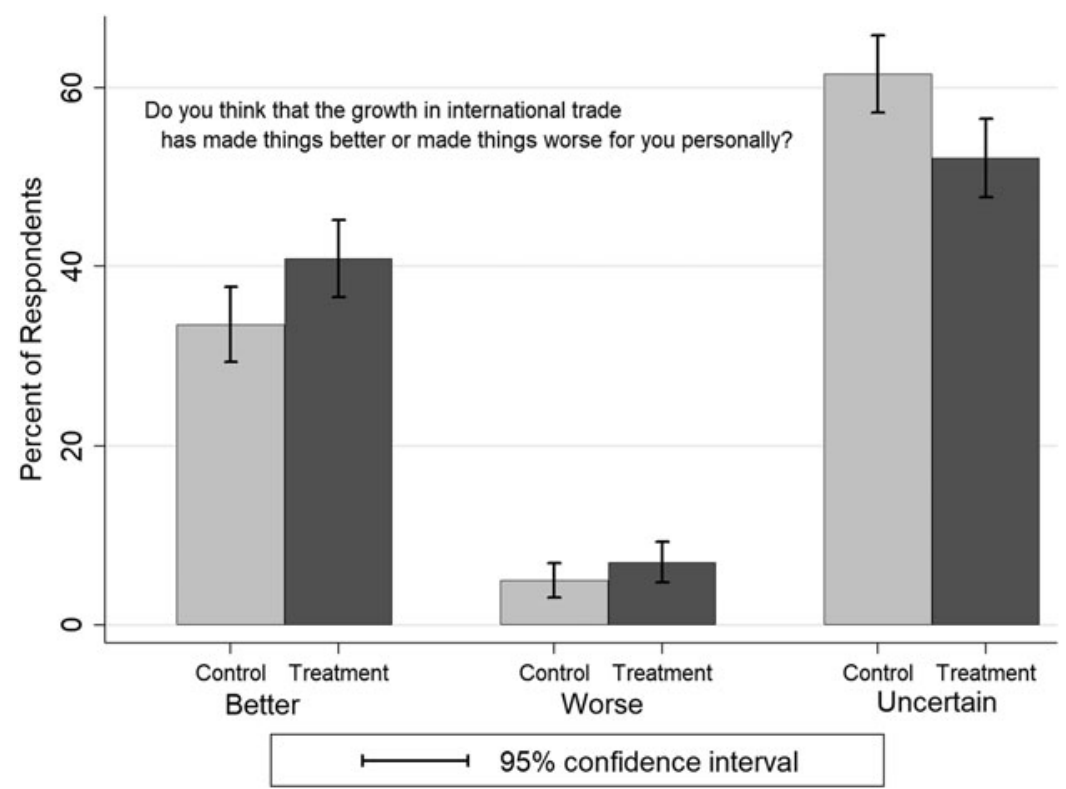

Fig. 1. Egotropic perceptions of trade by experimental group.

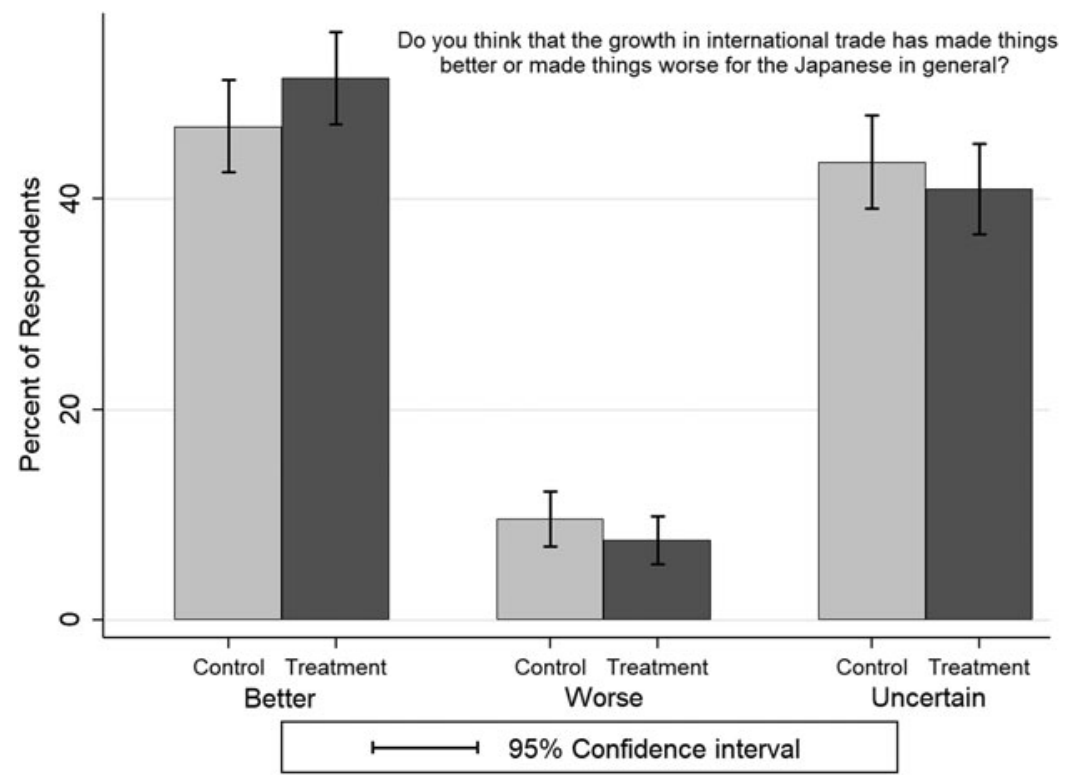

Fig. 2. Sociotropic perceptions of trade by experimental group.

examine how the groups are different, adjusted standardized residuals are calculated. Adjusted standardized residuals indicate the variation between observed and expected totals in each cell and are standardized to allow comparisons between cells. ${ }^{10}$ The sign of the residuals signifies the direction of the variation. Adjusted residuals follow a standard normal distribution and can thus be interpreted as $z$-scores. As

\footnotetext{
${ }^{10}$ Adjusted standardized residuals are calculated using TAB_CHI (Cox, 2016).
} 
Table 3. $\chi^{2}$ Test (egotropic perceptions of trade)

\begin{tabular}{llll}
\hline \multirow{2}{*}{$\begin{array}{l}\text { Experimental } \\
\text { Group }\end{array}$} & \multicolumn{3}{c}{ Egotropic perceptions of trade } \\
\cline { 2 - 4 } & \multicolumn{1}{c}{ Beneficial } & Harmful & Uncertain \\
\hline Control & $168(33.53 \%)$ & $25(4.99 \%)$ & $308(61.48 \%)$ \\
Socio treatment & {$[-2.404]$} & {$[-1.348]$} & {$[2.992]$} \\
& $204(40.88 \%)$ & $35(7.01 \%)$ & $260(52.10 \%)$ \\
\hline
\end{tabular}

Notes: Observed frequencies with row percentages in parenthesis. Adjusted standardized residuals are listed in brackets. $N=1000 \chi^{2}=9.70 P=0.01$.

indicated by the positive adjusted residual, 2.40 , respondents in the socio treatment are more likely to view trade as personally beneficial and there is a high level of confidence in this effect $(P<0.05) .{ }^{11}$

Following the sociotropic model, it is expected that thinking about the societal effects of trade will influence perceptions about the personal impact of trade by reducing uncertainty about the pocketbook effects of foreign policy. It is thus anticipated that uncertainty about the personal effects of trade should be reduced by the sociotropic treatment. In line with this expectation, the adjusted residual, -2.99 , is negative and statistically significant $(P<0.05)$.

Hypothesis 2 states that individuals' perceptions about the effect of trade on society are shaped by beliefs about the personal impact of trade. If this hypothesis is supported, the ego treatment will influence sociotropic trade attitudes. To test this relationship, we can compare the perceptions of the social impact of trade of the socio-control group to the ego-treatment group. The socio-control group directly received the sociotropic measure, how has international trade affected Japan in general, while the egotreatment group received the sociotropic measure after receiving the egotropic treatment. The only difference between the two groups is thus the egotropic treatment.

The results of the analysis are presented in Figure 2. If egocentric concerns influence sociotropic attitudes, we would expect the sociotropic attitudes of the groups to differ. A chi-squared test, however, fails to reject the null hypothesis that the groups are equal, $\chi^{2}(2, N=1,000)=2.67, P=0.26$ (Table 4).

\section{Trade policy preferences}

The following section provides a brief analysis of the effect of sociotropic and egotropic attitudes on trade-policy preferences. Though the main focus of this article is examining the relationship between egotropic and sociotropic interests it is also important to consider how these attitudes impact tradepolicy preferences. It should be acknowledged, however, that socio and egotropic attitudes are not independent. Specifically, sociotropic attitudes influence egotropic attitudes mainly by reducing uncertainty about the pocketbook effects of national policy. We should thus be cautious when comparing the effects of sociotropic and egotropic attitudes on policy preferences.

Trade-policy preferences are measured by responses to the following question: Which of the following statements comes closest to your own position? (1) Goods made in other countries should be imported and sold here if people want to buy them, (2) There should be stricter limits on selling foreign goods here to protect the jobs of people in Japan and (3) Not sure. The policy question is asked after and spaced as far as possible from the egotropic and sociotropic measures. A total of $65 \%$ of respondents supported open trade, while $15 \%$ preferred protection. This relatively high level of support for trade in Japan is consistent with other general measure of trade attitudes in Japan. About $20 \%$ of respondents indicated an uncertain response. The dependent variable protect trade is formed

\footnotetext{
${ }^{11}$ The effects are constant across demographic groups such as gender, age, and education. Women, for example, express a higher level of uncertainty about the egotropic effects of trade than men. Both women and men, however, express lower levels of uncertainty following the sociotropic treatment although the gap between the two remains. This is true for the elderly and non-college graduates as well.
} 
Table 4. $\chi^{2}$ Test (sociotropic perceptions of trade)

\begin{tabular}{llll}
\hline \multirow{2}{*}{$\begin{array}{l}\text { Experimental } \\
\text { Group }\end{array}$} & \multicolumn{3}{c}{ Sociotropic perceptions of trade } \\
\cline { 2 - 4 } & \multicolumn{1}{c}{ Beneficial } & Harmful & Uncertain \\
\hline Control & $234(46.89 \%)$ & $48(9.62 \%)$ & $217(43.49 \%)$ \\
& {$[-1.456]$} & {$[1.147]$} & {$[0.822]$} \\
Ego treatment & $258(51.50 \%)$ & $38(7.58 \%)$ & $205(40.92 \%)$ \\
& {$[1.456]$} & {$[-1.147]$} & {$[-0.822]$} \\
\hline
\end{tabular}

Notes: Observed frequencies with row percentages in parenthesis. Adjusted standardized residuals are listed in brackets. $N=1000 \chi^{2}=2.67 P=0.263$.

with those supporting protection coded 3, unsure coded as a middle category, and those supporting liberalization coded as $1 .{ }^{12}$

Model 1 in Table 5 presents a basic model of trade policy preferences standard to many studies examining $\mathrm{H}-\mathrm{O}$ predictions. Skill is measured by college education and income. It is predicted that low-skill and low-income individuals are more likely to support protection. Age, gender, political ideology, and unemployment may likewise impact trade attitudes and are thus accounted for.

The model performs largely as expected. College graduates and high-income earners are less supportive of protection as predicted by the factors model. Women and individuals with a conservative political ideology are more supportive of protection as is typically found. Surprisingly, however, age is negatively associated with support for protection. This result, however, may be related to the large number of elderly in Japan who are outside of labor markets.

Model 2 considers the impact of sociotropic attitudes. The measure sociotropic benefit ranges from 1-3 with individuals who believe trade benefits Japan in general coded as 3 , those who believe trade is harmful coded as 1 , and unsure is treated as middle category. Once the sociotropic variable is included the measure of skill is no longer significant as previously found by Mansfield and Mutz (2009) suggesting that pocketbook concerns are diminished once sociotropic attitudes are accounted for. Income and the other variables, on the other hand, remain significant and in the predicted direction except for gender. After accounting for sociotropic attitudes, gender is no longer a significant predictor.

Finally Model 3 incorporates an equivalent measure of egotropic attitudes. The measure egotropic benefit is coded 3 for individuals who believe trade benefits them personally, 1 for those who believe trade is personally harmful, and 2 for those who are unsure. The egotropic measure is statistically significant and has a similar impact as the sociotropic measure. When measured equivalently, both egotropic and sociotropic attitudes influence trade-policy preferences.

\section{Public support for trade}

The above experiment finds that sociotropic attitudes impact egotropic concerns mainly through reducing uncertainty about the pocketbook effects of trade policy. In contrast, there is no evidence that individuals project pocketbook concerns onto society. Priming about the personal impact of trade has no influence on beliefs about the societal effects of trade. Despite this, pocketbook concerns are still found to have a major impact on policy-preference formation. When measuring sociotropic and egotropic attitudes equally, both influence trade-policy preferences. These results have direct implications for Japanese trade politics.

While there is little general support for protection in Japan, the public is overwhelmingly unsure about both the personal and societal effects of trade liberalization. Special interest groups facing losses from open trade have been successful in shifting pubic support towards protection by emphasizing

\footnotetext{
${ }^{12}$ Treating the dependent variable as 3 separate categories and estimating a multinomial logit produces substantively and significantly equivalent results to the ordinal measure. See supplemental material for details of the results.
} 
Table 5. Trade-policy preferences

\begin{tabular}{|c|c|c|c|}
\hline Variables & $\begin{array}{c}(1) \\
\text { Model } 1\end{array}$ & $\begin{array}{c}(2) \\
\text { Model } 2\end{array}$ & $\begin{array}{c}\text { (3) } \\
\text { Model } 3\end{array}$ \\
\hline College Grad. & $\begin{array}{r}-0.187^{\star \star} \\
(0.0944)\end{array}$ & $\begin{array}{l}-0.124 \\
(0.0961)\end{array}$ & $\begin{array}{c}-0.114 \\
(0.0965)\end{array}$ \\
\hline Income & $\begin{array}{c}-0.0428^{\star *} \\
(0.0167)\end{array}$ & $\begin{array}{c}-0.0415^{\star *} \\
(0.0169)\end{array}$ & $\begin{array}{c}-0.0343^{\star *} \\
(0.0172)\end{array}$ \\
\hline Age & $\begin{array}{c}-0.0304^{\star \star} \\
(0.0143)\end{array}$ & $\begin{array}{c}-0.0214 \\
(0.0146)\end{array}$ & $\begin{array}{c}-0.0239 \\
(0.0147)\end{array}$ \\
\hline Female & $\begin{array}{r}0.210^{\star \star} \\
(0.0902)\end{array}$ & $\begin{array}{c}0.160^{\star} \\
(0.0916)\end{array}$ & $\begin{array}{c}0.136 \\
(0.0922)\end{array}$ \\
\hline Conservative & $\begin{array}{l}0.0750^{\star \star \star *} \\
(0.0240)\end{array}$ & $\begin{array}{l}0.0936^{\star * *} \\
(0.0245)\end{array}$ & $\begin{array}{l}0.0935^{\star \star \star} \\
(0.0246)\end{array}$ \\
\hline Unemployed & $\begin{array}{c}0.267 \\
(0.208)\end{array}$ & $\begin{array}{c}0.196 \\
(0.210)\end{array}$ & $\begin{array}{c}0.167 \\
(0.211)\end{array}$ \\
\hline Sociotropic benefit & & $\begin{array}{c}-0.448^{* * *} \\
(0.0695)\end{array}$ & $\begin{array}{c}-0.326^{\star * *} \\
(0.0828)\end{array}$ \\
\hline Egotropic benefit & & & $\begin{array}{c}-0.256^{\star \star \star} \\
(0.0955)\end{array}$ \\
\hline Cut 1 & $\begin{array}{l}0.566^{\star * *} \\
(0.185)\end{array}$ & $\begin{array}{c}-0.342 \\
(0.233)\end{array}$ & $\begin{array}{c}-0.636^{\star \star} \\
(0.258)\end{array}$ \\
\hline Cut 2 & $\begin{array}{l}1.134^{\star \star \star} \\
(0.188)\end{array}$ & $\begin{array}{c}0.246 \\
(0.234)\end{array}$ & $\begin{array}{c}-0.0452 \\
(0.258)\end{array}$ \\
\hline Observations & 840 & 840 & 840 \\
\hline
\end{tabular}

Dependent variable $=$ Protect trade.

Standard errors in parentheses.

${ }^{\star \star \star} P<0.01,{ }^{\star \star} P<0.05,{ }^{\star} P<0.1$.

possible harms to society. As shown in the priming experiment, these perceived societal effects further influence individuals' perceptions about the pocketbook effects of trade.

Consider, for example, public support for the TPP. In 2010, when regular polls were first being conducted on the topic about $19 \%$ of the public opposed the deal while $61 \%$ supported Japan joining. And about $18 \%$ of the public was unsure whether they approved or opposed the TPP (Naoi and Urata, 2013). These results are very similar to the attitudes toward general trade reported in this study. The Ministry of Agriculture, Fishing, and Farming (MAFF) estimated that entry into the TPP would diminish Japanese agricultural production and cause over eight trillion yen in economic losses for the nation. The Japan Agricultural Cooperative (JA) launched a large-scale campaign to caution the public of the possible harms of the TPP and warned of the eradication of Japanese farming and low-quality imports. This operation proved rather successful. By 2011, JA had amassed 11.7 million signatures opposing the TPP (Hearn, 2018). As JA and other interest groups fought to frame the trade agreement, public opposition to the TPP rose and support waned.

Support for the TPP fell from over 60\% in 2010 to around 44\% in 2012 (Naoi and Urata, 2013). Following the results of the above experiment, a possible explanation for JA and other groups' success is the dual effect of sociotropic interests. Sociotropic interests not only directly influence attitudes but likewise indirectly impact preferences by affecting egotropic perceptions. Previous work has considered how trusted sources, information campaigns, and cues influence attitudes toward globalization (Naoi and Urata, 2013; Plouffe and Kuo, 2016; Bearce and Tuxhorn, 2017). Building upon this, future work should consider the effectiveness of sociotropic vs egotropic information campaigns. Although egotropic attitudes are important, the public has difficulty relating pocketbook outcomes to foreign policy. Information campaigns framing the societal effects of globalization thus have the potential to influence public opinion both directly and indirectly by also shaping egotropic perceptions.

Supplementary material. The supplementary material for this article can be found at https://doi.org/10.1017/ S1468109919000124 and https://dataverse.harvard.edu/dataset.xhtml?persistentId=doi:10.7910/DVN/KZK409 
Acknowledgements. A previous version of this research was presented at the 2018 Pacific International Politics Conference (PIPC) at Hong Kong University. I would like to thank the participants at PIPC who provided me with helpful feedback. I would also like to thank the anonymous reviewers and editors whose comments and suggestions greatly improved the quality of the text.

Financial support. This work is supported by JSPS KAKENHI Grant Number 17K18268

Conflict of interest. The author declared no potential conflicts of interest with respect to the research, authorship, and/or publication of this article.

\section{References}

Ardanaz M, Murillo MV and Pinto PM (2013) Sensitivity to issue framing on trade policy preferences: evidence from a survey experiment. International Organization 67, 411-437.

Baker A (2003) Why is trade reform so popular in Latin America. World Politics 55, 423-455.

Baker A (2005) Who wants to globalize? Consumer tastes and labor markets in a theory of trade policy beliefs. American Journal of Political Science 49, 924-938.

Balistreri EJ (1997) The performance of the Heckscher-Ohlin-Vanek model in predicting endogenous policy forces at the individual level. Canadian Journal of Economics, 1-17.

Bearce DH and Tuxhorn K-L (2017) When are monetary policy preferences egocentric? Evidence from American surveys and an experiment. American Journal of Political Science 61, 178-193.

Beaulieu E (2002) Factor or industry cleavages in trade policy? An empirical analysis of the Stolper-Samuelson theorem. Economics \& Politics 14, 99-131.

Colantone I and Stanig P (2018) The trade origins of economic nationalism: import competition and voting behavior in Western Europe. American Journal of Political Science 62, 936-953.

Cox NJ (2016) TAB_CHI: Stata Modules for Tabulation of Multiple Variables in Stata 8.2 or Better. Statistical Software Components. Boston College Department of Economics. Available at https://ideas.repec.org/c/boc/bocode/s368901.html (Accessed 3 May 2019).

Curtis KA (2014) In times of crisis: the conditions of pocketbook effects. International Interactions 40, 402-430.

Ehrlich SD (2010) The fair trade challenge to embedded liberalism. International Studies Quarterly 54, 1013-1033.

Ehrlich S (2018) The Politics of Fair Trade: Moving Beyond Free Trade and Protection. New York City: Oxford University Press.

Ehrlich SD and Hearn E (2014) Does compensating the losers increase support for trade? An experimental test of the embedded liberalism thesis. Foreign Policy Analysis 10, 149-164.

Feldman S (1982) Economic self-interest and political behavior. American Journal of Political Science, 446-466.

Fordham BO and Kleinberg KB (2012) How can economic interests influence support for free trade? International Organization 66, 311-328.

Gomez BT and Wilson JM (2001) Political sophistication and economic voting in the American electorate: a theory of heterogeneous attribution. American Journal of Political Science, 899-914.

Guisinger A (2017) American Opinion on Trade: Preferences Without Politics. New York City: Oxford University Press.

Hainmueller J and Hiscox MJ (2006) Learning to love globalization: education and individual attitudes toward international trade. International Organization 60, 469-498.

Hainmueller J and Hiscox MJ (2010) Attitudes toward highly skilled and low-skilled immigration: evidence from a survey experiment. American Political Science Review 104, 61-84.

Hays JC, Ehrlich SD and Peinhardt C (2005) Government spending and public support for trade in the OECD: an empirical test of the embedded liberalism thesis. International Organization 59, 473-494.

Hearn E (2014) Harm, fairness and trade policy preferences: an experimental examination of sincere fair-trade preferences. International Politics 51, 124-135.

Hearn E (2017) Buying Globalization: Consumer Tastes and Trade-Policy Preference Formation. paper presented at the Korean Political Science Association World Congress, Seoul, ROK (23 June).

Hearn E (2018) Constituency size and responsiveness to sectoral interests: the case of Japan and the trans-pacific partnership. Politics \& Policy.

Irwin DA (1994) The political economy of free trade: voting in the British general election of 1906. The Journal of Law and Economics 37, 75-108.

Jensen JB, Quinn DP and Weymouth S (2017) Winners and losers in international trade: the effects on US presidential voting. International Organization 71, 423-457.

Kaempfer WH and Marks SV (1993) The expected effects of trade liberalisation: evidence from US congressional action on fast-track authority. The World Economy 16, 725-740.

Kertzer JD and Brutger R (2016) Decomposing audience costs: bringing the audience back into audience cost theory. American Journal of Political Science 60, 234-249. 
Lockerbie B (2006) Economics and politics: egocentric or sociotropic? American Review of Politics 27, 191-208.

Lï X, Scheve K and Slaughter MJ (2012) Inequity aversion and the international distribution of trade protection. American Journal of Political Science 56, 638-654.

Magee SP (1978) Three simple tests of the stolper-samuelson theorem. In Oppenheimer P (ed.), Issues in International Economics. Stocksfield, England: Oriel Press, pp. 138-153.

Malhotra N, Margalit Y and Mo CH (2013) Economic explanations for opposition to immigration: distinguishing between prevalence and conditional impact. American Journal of Political Science 57, 391-410.

Mansfield ED and Mutz DC (2009) Support for free trade: self-interest, sociotropic politics, and out-group anxiety. International Organization 63, 425-457.

Mayda AM (2006) Who is against immigration? A cross-country investigation of individual attitudes toward immigrants. The Review of Economics and Statistics 88, 510-530.

Mayda AM and Rodrik D (2005) Why are some people (and countries) more protectionist than others? European Economic Review 49, 1393-1430.

Naoi M and Kume I (2011) Explaining mass support for agricultural protectionism: evidence from a survey experiment during the global recession. International Organization 65, 771-795.

Naoi M and Kume I (2015) Workers or consumers? A survey experiment on the duality of citizens' interests in the politics of trade. Comparative Political Studies 48, 1293-1317.

Naoi $\mathbf{M}$ and Urata S (2013) Free trade agreements and domestic politics: the case of the trans-pacific partnership agreement. Asian Economic Policy Review 8, 326-349.

O'Rourke KH and Sinnott R (2001) The determinants of individual trade policy preferences: international survey evidence. In Collins AM and Rodrik D, eds., Brookings Trade Forum. Washington, DC: Brookings Institution Press. pp. 157-206.

Owen E and Johnston NP (2017) Occupation and the political economy of trade: job routineness, offshorability, and protectionist sentiment. International Organization 71, 665-699.

Owen E and Walter S (2017) Open economy politics and Brexit: insights, puzzles, and ways forward. Review of International Political Economy 24, 179-202.

Plouffe M and Kuo J (2016) Do electoral campaigns influence public support for trade? Evidence from the 2016 US Presidential Election. SSRN. Available at https://papers.ssrn.com/sol3/papers.cfm?abstract_id=3278778.

Quek K (2017) Type II audience costs. The Journal of Politics 79, 1438-1443.

Rehm P (2009) Risks and redistribution an individual-level analysis. Comparative Political Studies 42, 855-881.

Rho S and Tomz M (2015) Industry, Self-Interest, and Individual Preferences Over Trade Policy. unpublished manuscript, Stanford University. Available at https://web.stanford.edu/ tomz/working/RhoTomz-2015-04-01.pdf

Rho S and Tomz M (2017) Why don't trade preferences reflect economic self-interest? International Organization 71, S85S108.

Sanz I and i Coma FM (2008) Skill and support to globalization in the EU. Applied Economics Letters 15, 271-275.

Scheve KF and Slaughter MJ (2001a) Labor market competition and individual preferences over immigration policy. Review of Economics and Statistics 83, 133-145.

Scheve KF and Slaughter MJ (2001b) What determines individual trade-policy preferences? Journal of International Economics 54, 267-292.

Spilker G, Bernauer T and Umaña V (2016) Selecting partner countries for preferential trade agreements: experimental evidence from Costa Rica, Nicaragua, and Vietnam. International Studies Quarterly. Available at http://isq.oxfordjournals.org/ content/early/2016/02/13/isq.sqv024.abstract (Accessed 4 August 2016).

Tomiura E, Ito B, Mukunoki $\mathbf{H}$ and Wakasugi R (2016) Individual characteristics, behavioral biases, and trade policy preferences: evidence from a survey in Japan. Review of International Economics 24, 1081-1095. doi: 10.1111/roie.12248.

Weatherford MS (1983) Economic voting and the 'symbolic politics' argument: a reinterpretation and synthesis. American Political Science Review 77, 158-174.

Cite this article: Hearn E (2020). Disentangling the relationship between sociotropic and egotropic trade attitudes: A survey experiment in Japan. Japanese Journal of Political Science 21, 31-42. https://doi.org/10.1017/S1468109919000124 